\title{
Phenology of Zostera caespitosa in Tongyeong on the coast of Korea
}

\author{
Joon-Sik Yoon ${ }^{1}$, Nam-Gil Kim ${ }^{2, *}$ \\ ${ }^{1}$ Korea Fisheries Resources Agency, Busan 46041, Korea \\ ${ }^{2}$ Department of Marine Biology and Aquaculture, Gyeongsang National University, Tongyeong 53064, Korea
}

\begin{abstract}
The variations of morphological features, density and biomass of vegetative shoots and characteristics of reproductive shoots of Zostera caespitosa were examined in Tongyeong, Korea. Morphological features such as leaf length, width and sheath length of $Z$. caespitosa showed significant seasonal variation $(p<0.001)$. The highest aboveground value was recorded in late spring to summer and the lowest value in winter. Density and biomass also showed seasonal variations. Annual average shoot density and biomass of $Z$. caespitosa were recorded as 1,223.4 leaf $\mathrm{m}^{-2}$ and 5,956.9 g w.w. $\mathrm{m}^{-2}$, respectively, and had the highest value in June and lowest values in November and January. Reproductive shoots were observed from April $\left(13^{\circ} \mathrm{C}\right)$ to June $\left(21^{\circ} \mathrm{C}\right)$. Pistils erected outside sheath, anther dehiscing and small embryos were found in April. Mature fruit and released seeds were found in May and June. These results suggest that this species had a high growth rate in late spring and early summer $\left(15^{\circ} \mathrm{C}-20^{\circ} \mathrm{C}\right)$. Reproductive shoots of $Z$. caespitosa may initially appear at about $10^{\circ} \mathrm{C}$ in spring and seed have been released at about $20^{\circ} \mathrm{C}$ in fall.
\end{abstract}

Keywords: Zostera caespitosa, Density, Biomass, Mature, Tongyeong

\section{Introduction}

About 60 seagrasses are distributed worldwide except for the Antarctic (Den Hartog, 1970; Phillips \& Menez, 1988; Short et al., 2007). Among them, 9 species (five species in genus Zostera, two species in genus Phyllospadix, one species in genus Ruppia and one species in genus Halophila) are found on the Korean coast (Kim et al., 2009; Lee \& Lee, 2003; Lee et al., 2018; Shin et al., 2002 ).

Zostera caespitosa has been considered one of the endemic species in this region (Omori, 1993). This species can easily be distinguished from other species genus of Zostera by their non-generated creeping rhizomes, extremely shortened internodes, obcordate leaf apex and separately tufted appearance (Kuo \& Den Hartog, 2001; Shin \& Choi, 1998). Leaf blades of $Z$. caespitosa grow up to $70 \mathrm{~cm}$ tall and $2.5-4.5 \mathrm{~mm}$ wide and 6-10 male and female flowers are arranged per spadix (Kuo \& Den Hartog, 2001).

Seagrasses reproduce in two ways, sexually by flowering and asexually by clonal growth (Den Hartog, 1970; Eriksson, 1989; Eriksson \& Froborg, 1996). Asexual reproduction has been considered the dominant process for the establishment and mainte-

Received: Jan 4, 2021 Revised: Feb 1, 2021 Accepted: Feb 16, 2021

*Corresponding author: Nam-Gil Kim

Department of Marine Biology and Aquaculture, Gyeongsang National University, Tongyeong 53064, Korea

Tel: +82-55-772-9155, Fax: +82-55-772-9159, E-mail: ngkim@gnu.ac.kr

This is an Open Access article distributed under the terms of the Creative Commons Attribution Non-Commercial License (http://creativecommons.org/licenses/by$\mathrm{nc} / 4.0 /$ ) which permits unrestricted non-commercial use, distribution, and reproduction in any medium, provided the original work is properly cited.

Copyright $\odot 2021$ The Korean Society of Fisheries and Aquatic Science 
nance of seagrass meadows (Hemminga \& Duarte, 2000). Sexual reproduction is an important mechanism to maintain the genetics and regeneration of many seagrass populations (Kendrick et al., 2012, 2017 ; Orth et al., 2000; Plus et al., 2003).

Seagrasses are considered to be one of the most important shallow marine ecosystems by various roles that provide habitats and nursery grounds for fish and invertebrates as well as filtering coastal waters and anchoring sediments (Costanza et al., 1997; Green \& Short, 2003; Orth et al., 2006).

Seagrass meadows have been disappearing at a rate of 110 $\mathrm{km}^{2}$ a year since 1980 (Short \& Wyllie-Echeverria, 1996; Waycott et al., 2009). This is a result of disturbances by nature and human activity such as grazing herbivores, hurricanes, harbor construction, and sewage disposal.

There have been few studies on Z. caespitosa in Korea (Lee et al., 2002, 2005b, 2005c). In this study, to clarify the phenology of $Z$. caespitosa, we investigated the variation of morphological features, density, biomass and characteristics of reproductive shoots of $Z$. caespitosa in Tongyeong, Korea. We should provide not only valuable information on the biology and ecology of this species but also more detail characteristics on reproductive shoots.

\section{Materials and Methods}

\section{Description of study area}

This study was carried out in Tongyeong on the southern coast of Korea (Fig. 1). Three seagrasses (Z. caespitosa, Z. marina and $H$. nipponica) were found in this area. These seagrasses had different distributed depths; $H$. nipponica was found in shallow

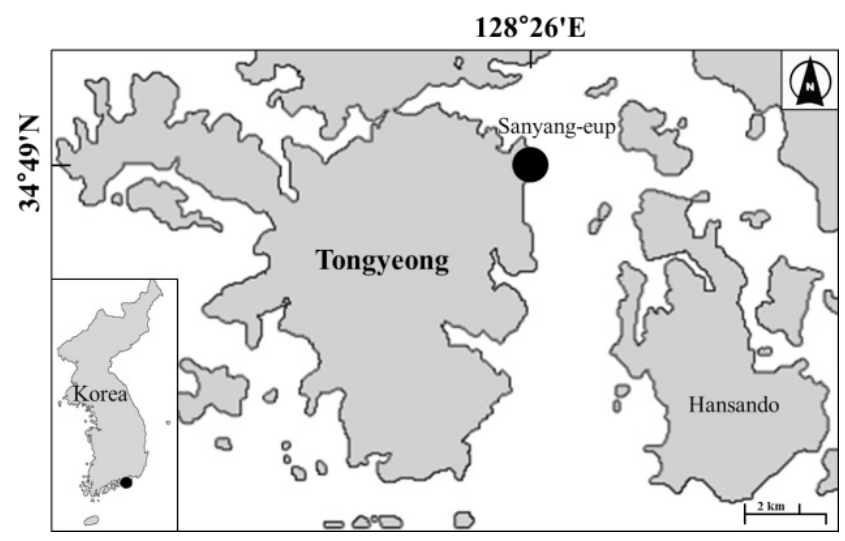

Fig. 1. A map showing collecting site at Tongyeong coast in Korea. water at a depth of 1-2 m. $Z$ marina and $Z$. caespitosa were found at depths of 1-3 m and 3-5 m, respectively. The meadow of $Z$. caespitosa showed a monotypic form at a depth of $5 \mathrm{~m}$ and mixed form at a depth of $3 \mathrm{~m}$ depth with $Z$. marina. This coast is open sea, not sheltered by wave action, and the sediment has a sand-muddy composition. Water temperature and salinity data were obtained from the Korea Hydrographic and Oceanographic Administration (http://www.khoa.go.kr).

\section{Sample collection and analysis of plants}

In this study, Z. caespitosa was collected in the study area from January to December 2016 by skin scuba diving. To determine density and biomass, a $50 \mathrm{~cm} \times 50 \mathrm{~cm}$ quadrat was used, which contained three tufts in a quadrat. Above ground morphological features such as leaf, sheath length, leaf width and density, and biomass were measured monthly. The number of leaves and plant biomass in the quadrat were measured and converted to unit area values. Shoot height and the length and width of reproductive shoots were also measured during the reproductive shoot period.

\section{Characteristics of inflorescence}

The development of inflorescence on $Z$. caespitosa was classified according to the modified division method by Yoon (2019), which was adapted from Alexandre et al., 2005. Maturity development of spathe on genus Zostera was divided into six stages, with zero as undefined flowers inside the immature inflorescence; I, flowers aligned on a single stem and sheath closed; II, mature females erected outside sheath for fertilization; III, filiform pollen released by mature males (anther dehiscing); IV, fertilized females, thecae empty (if still present); and V, presence of fruits (Va, small embryos inside the female flowers; $\mathrm{Vb}$, fully developed fruit; Vc, creviced fruit skin [ready for seed release]; $\mathrm{Vd}$, released seed [only fruit skin remaining, without seed]). The length and width of the spathe and spadix, weight of spathe and fruit, and number of anthers, pistils and fruits per spadix were measured during the flowering period.

\section{Statistical analysis}

Statistical analyses were performed using the SPSS Windows program (Release 20.0, SPSS, Chicago, IL, USA ). Monthly variation of morphological features and characteristics of inflorescence were analyzed by one-way analysis of variance (ANOVA). When a significant difference was observed, the means were analyzed by Duncan's multiple range test to establish significant 
differences among them $(p<0.05)$. The relationship between water temperature and morphological features was estimated using curve estimation, and the significances of these regressions were tested using ANOVA with the significance level set at 0.05 . All values are reported as mean $95 \%$ confidence interval $\pm 95 \%$ confidence interval.

\section{Results}

\section{Water temperature and salinity}

There were clear seasonal variations in water temperature in the study area, but not salinity (Fig. 2). The annual mean values of temperature and salinity were $17.2 \pm 7.1^{\circ} \mathrm{C}$ and $34.3 \pm 0.2 \mathrm{psu}$, respectively, and they had the highest value each in August (29.2 $\left.\pm 2.1^{\circ} \mathrm{C}\right)$ and February $(34.3 \pm 0.2 \mathrm{psu})$ and lowest value each in February $\left(6.3 \pm 0.9^{\circ} \mathrm{C}\right)$ and September $(28.7 \pm 0.4 \mathrm{psu})$.

\section{Morphological variation of vegetative shoots}

Above ground, $Z$. caespitosa showed clear seasonal variations in leaf and sheath length and leaf width, $(p<0.001)$ and displayed a significant positive linear relationship $\left(R^{2}=0.15,0.54,0.21\right.$, $p<0.001$ for each leaf and sheath length and leaf width). Leaf length increased in spring (March) to early summer (June) and dramatically decreased in midsummer (July) and then slowly decreased. The highest value of leaf was $141.4 \pm 3.2 \mathrm{~cm}$ in June and lowest value was $55.9 \pm 2.8 \mathrm{~cm}$ in November. Sheath length also increased from spring to midsummer and decreased in late summer in August. The highest sheath value was recorded in July $(16.3 \pm 0.9 \mathrm{~cm})$ and the lowest value in January $(8.3 \pm 1.8$

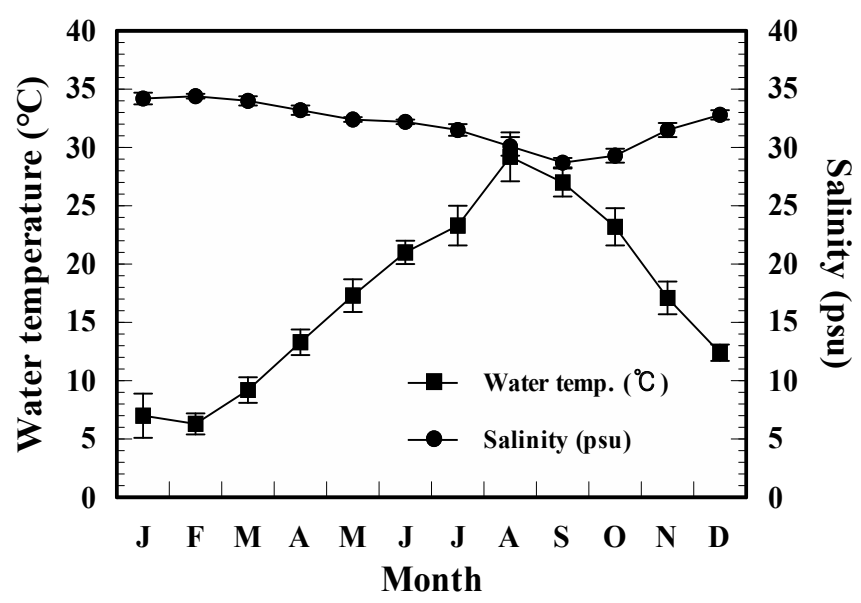

Fig. 2. Monthly variation of water temperature and salinity at Tongyeong coast in Korea. $\mathrm{cm})$. The widest value of leaves was recorded in May at $5.0 \pm$ $1.1 \mathrm{~mm}$ and the narrowest in winter (January) at $4.0 \pm 0.7 \mathrm{~mm}$. Leaves grew gradually wider in spring, were the widest in spring and slowly became narrower in fall (Fig. 3).

\section{Morphological variation of reproductive shoots}

The reproductive shoots of $\mathrm{Z}$. caespitosa occurred from April $\left(13.3 \pm 1.1^{\circ} \mathrm{C}\right)$ to June $\left(21.0 \pm 1.0^{\circ} \mathrm{C}\right)$ and disappeared after June. Shoot height, leaf length and width of reproductive shoots showed monthly variations $(p<0.001)$. The average height of reproductive shoots was recorded as $155.6 \pm 18.6 \mathrm{~cm}$, with the longest in June $(168.7 \pm 2.4 \mathrm{~cm})$ and shortest in April $(131.0 \pm 8.1$ $\mathrm{cm})$. The leaf length and width of reproductive shoots had the highest values in May, $29.7 \pm 4.2 \mathrm{~cm}$ and $3.3 \mathrm{~mm}$, respectively, and lowest values in June, $22.0 \pm 1.6 \mathrm{~cm}$ and $3.0 \pm 0.2 \mathrm{~mm}$, respectively (Fig. 3).

\section{Density and biomass}

Shoot density and biomass of $Z$. caespitosa showed seasonal variations, with an increasing tendency during spring and early summer, and dramatically decreasing in midsummer. The number of leaves ranged from 936 to 1,893.0 leaf $\mathrm{m}^{-2}$ and had the highest value in June and lowest value in November. Biomass ranged from 1,224.0 to $13,541.6 \mathrm{~g}$ w.w.m ${ }^{-2}$ and recorded the maximum value in June and minimum value in January (Fig. 4).

\section{Characteristics of inflorescence}

Inflorescence of $Z$. caespitosa exhibited various maturity stages from I to Va, with erected pistils (Fig. 5B), anther dehiscing (Fig. 5C) and small embryos (Fig. 5D) in April. In May, fully matured fruits were observed (stage Vb, Fig. 5E). In stage Vc, cracks in fruit skin, and in stage $\mathrm{Vd}$, traces of released seeds were observed in July (Fig. 5F). There was no significant difference in the length and width of spathe and spadix $(p>0.05)$, but there was a significant difference in the weight of spadix and fruits and the number of fruits $(p<0.001)$ between months in the flowering period. Spathe was longest and widest in May and April, at $6.9 \pm 0.9 \mathrm{~cm}$ $5.7 \pm 0.6 \mathrm{~mm}$, and shortest and narrowest in July, at $6.3 \pm 0.6$ $\mathrm{cm}$ and $5.3 \pm 0.3 \mathrm{~mm}$. Spadix was longest and widest in April, at $5.6 \pm 0.7 \mathrm{~cm}, 4.1 \pm 0.4 \mathrm{~mm}$, and shortest and narrowest in July, at $5.4 \pm 0.7 \mathrm{~cm}, 3.8 \pm 0.2 \mathrm{~mm}$. The weight of spathe in July was almost 3- to 4-fold higher than in April. The number of pistils and anthers per spadix were recorded as $10.0 \pm 2.6$ and $18.5 \pm$ 4.7 in April. Pistils and anthers were not observed after April. The highest number of fruits was seen in May (9.6 \pm 1.3$)$ and 

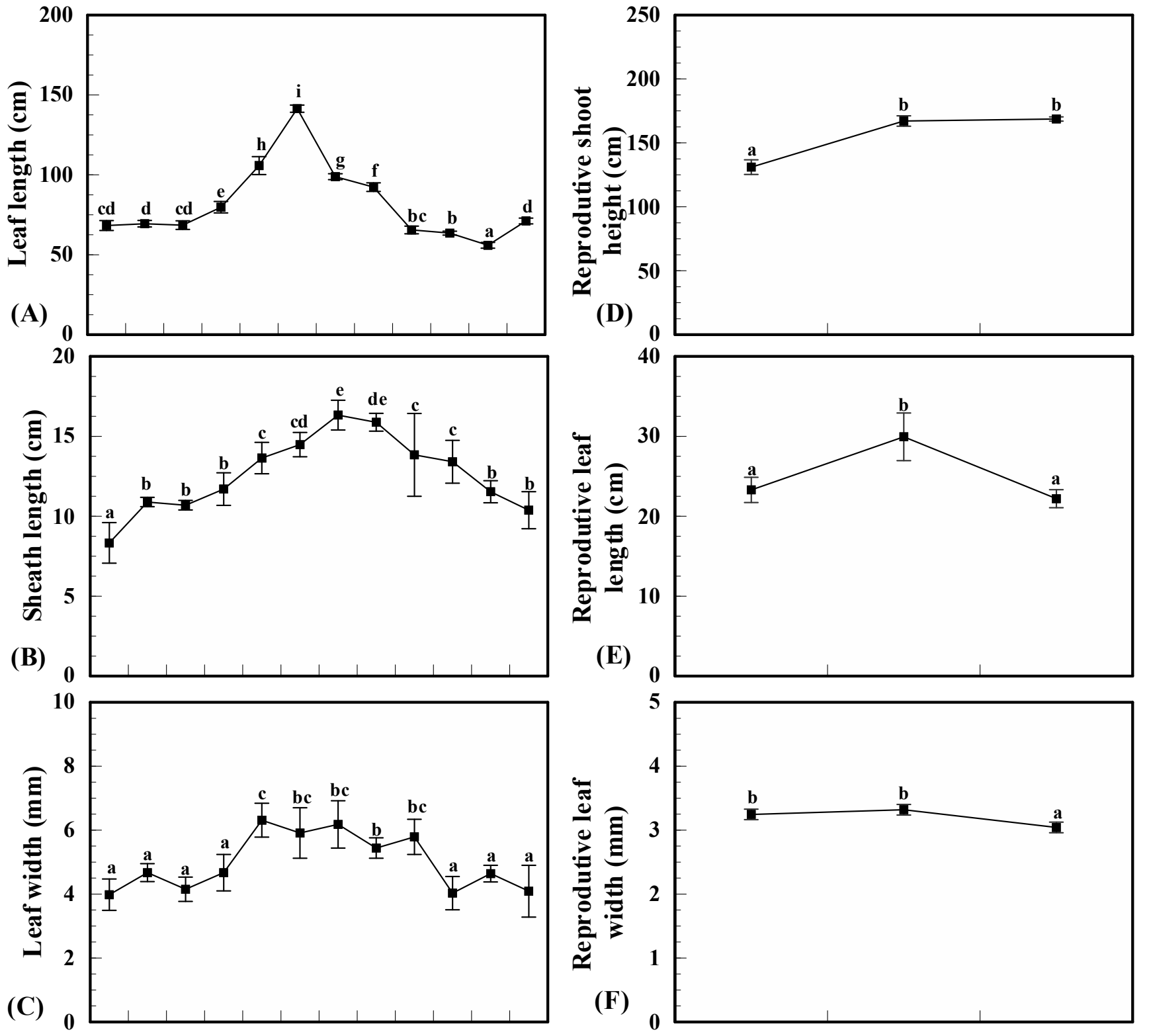

Fig. 3. Variation of above ground and reproductive shoot on Zostera caespitosa at Tongyoung from January to December 2016 and April to June: (A) leaf length, (B) sheath length, (C) leaf width, (D) Reproductive shoot height, (E) Reproductive leaf length, (F) Reproductive leaf width. Data are means 95\% confidence intervals. Different letters above bars indicate significant differences $(p<0.05)$.

the lowest in June (5.2 \pm 1.3$)$. Fruit wet weight was almost two to three times higher in July than in April (Table 1).

\section{Discussion}

Morphological features, density and biomass of seagrass usually exhibit seasonal variations, and these values were reported as fluctuating trends that increased during spring and summer and decreased in fall and winter (Dunton, 1994; Lee \& Dunton, 1997; Zhang et al., 2016). But in this study, the density, biomass and growth of $Z$. caespitosa increased in spring and early summer and decreased in midsummer, and these results are similar 


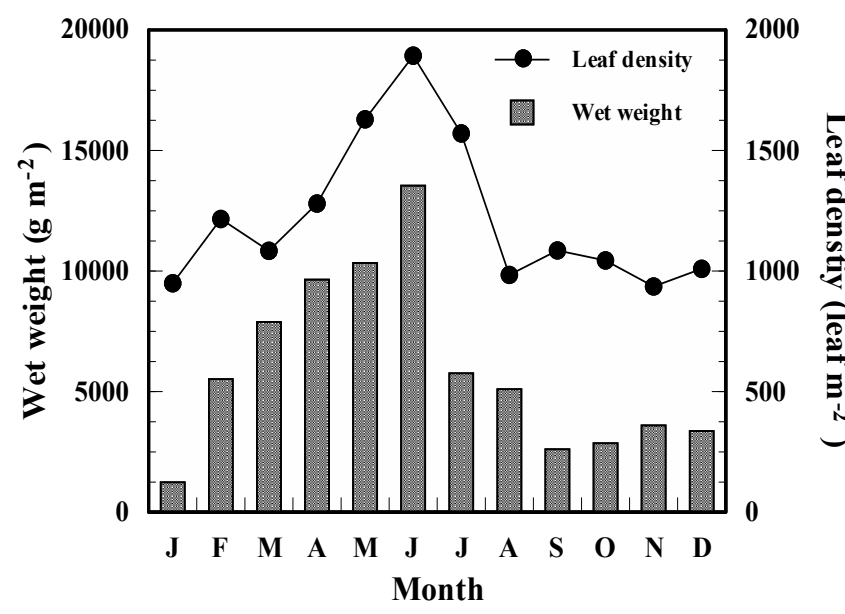

Fig. 4. Seasonal variation in leaf density and wet weight of Zostera caespitosa.

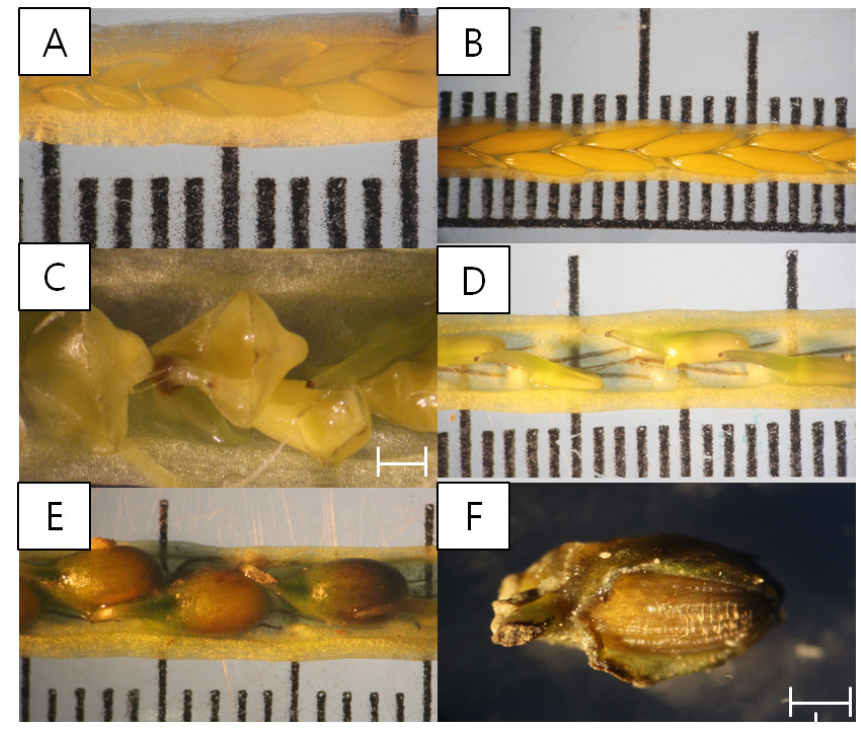

Fig. 5. Variation in maturation stage, spathe development of Zostera caespitosa: (A) maturation stage I, (B) maturation stage II, (C) maturation stage III, (D) maturation stage Va, (E) maturation stage $\mathbf{V b}$, (F) maturation stage Vc. All scare bars are $1 \mathrm{~mm}$.

to those of Lee et al. (2005c).

Water temperature has been considered a major factor in controlling growth, and this factor can limit the growth and germination of seagrass during high temperature periods (Biebl \& McRoy, 1971; Lee et al., 2007; Morita et al., 2010; Phillips et al., 1983). Seagrasses may show maximum growth with optimal water temperature, and photosynthetic rates decreased when over $30^{\circ} \mathrm{C}$ (Marsh et al., 1986). Höffle et al. (2011) reported that the mortality rate of $Z$. marina cultured at $27^{\circ} \mathrm{C}$ was higher than that cultured at $18^{\circ} \mathrm{C}$ and $21^{\circ} \mathrm{C}$. In the study site, the water temperature almost reached $30^{\circ} \mathrm{C}$ in August and at that time, leaf length, leaf density and biomass already decreased, so the decreasing tendency in midsummer coincided with the season of flowering shoot senescence.

The growth, morphological features, density and biomass of seagrass showed different values with environmental factors such as temperature, salinity, photon radiation, sediment and latitude (Bradley \& Stolt, 2006; Bulthuis, 1987; Livingston et al., 1998; Lee et al., 2005a; Phillips et al., 1983). Lee et al. (2005c), who conducted a studied on Geoje Island off the southern coast of Korea, reported that the blade length and width of $Z$. caespitosa ranged from 23.9 to $100.2 \mathrm{~cm}$ and 4.4 to $7.6 \mathrm{~mm}$, respectively. This indicated that $Z$. caespitosa distributed in our study area may be longer and narrower than that near Geoje Island. In our study, the shoot growth rate was optimal rate during the rising water temperature period from March $\left(13^{\circ} \mathrm{C}\right)$ to June $\left(21^{\circ} \mathrm{C}\right)$. This is similar to the study by Lee et al. (2005c).

It has been reported that there is no considerable variation in the number of shoots on $Z$. caespitosa (Lee et al., 2005c) but in this study, there was a clear seasonal variation in the number of leaves on $Z$. caespitosa $(p<0.001)$. This difference suggests that the number of leaves in turf fluctuates more than the number of shoots.

The relationship between water temperature and morphological features was significantly different $(p<0.001)$ but exhibited a poor relationship. This result may be related to the growth of $Z$. caespitosa showing a positive correlation in the rising water temperature period (spring, early summer) but show a negative correlation in the summer high temperature period.

Several studies have said that temperature is the most important factor that controls and regulates seagrass reproduction (Buia \& Mazzella, 1991; McMillan, 1976; Phillips et al., 1983). Alexandre et al. (2006) reported that the pollination process (Stages I-IV) required about 10 days for Z. noltii. In our study, various stages (I-Va) of inflorescence of $Z$. caespitosa were observed in April; therefore, the first occurrence of reproductive shoots may occur at the end of March $\left(10^{\circ} \mathrm{C}\right)$ and the time of appearance was similar to a study by Lee et al. (2005c). The flowering period was affected not only by water temperature, but also latitude and genetic variation (Phillips et al., 1983). Lee et al. (2005b) in a study in Ulpo, Korea reported that the reproductive shoots of $Z$. caespitosa observed from February $\left(10^{\circ} \mathrm{C}\right)$ to May 
Table 1. Variation of reproductive phase characteristics on Zostera caespitosa (mean $\pm \mathrm{SE}$ )

\begin{tabular}{|c|c|c|c|c|c|c|c|c|c|c|c|}
\hline & $\begin{array}{l}\text { Spathe } \\
\text { length }(\mathrm{cm})\end{array}$ & $\begin{array}{l}\text { Spathe } \\
\text { width (mm) }\end{array}$ & $\begin{array}{l}\text { Spadix } \\
\text { length }(\mathrm{cm})\end{array}$ & $\begin{array}{l}\text { Spadix } \\
\text { width (mm) }\end{array}$ & $\begin{array}{l}\text { Spathe wet } \\
\text { weight }(\mathrm{mg})^{*}\end{array}$ & NPS (ea) & NAS (ea) & WPS (mg) & WAS (mg) & NFS $(\mathrm{ea})^{*}$ & $\begin{array}{l}\text { Fruit wet } \\
\text { weight (mg)* }\end{array}$ \\
\hline April, 2016 & $6.6 \pm 1.2$ & $5.7 \pm 0.6$ & $5.6 \pm 0.7$ & $4.1 \pm 0.4$ & $149.3 \pm 75.3^{\mathrm{a}}$ & $10.0 \pm 2.6$ & $18.5 \pm 4.7$ & $10.4 \pm 5.2$ & $126.4 \pm 40.9$ & $6.8 \pm 1.0^{\mathrm{a}}$ & $7.2 \pm 1.2^{\mathrm{a}}$ \\
\hline May, 2016 & $6.9 \pm 0.9$ & $5.6 \pm 0.3$ & $5.5 \pm 1.8$ & $4.1 \pm 0.2$ & $312.6 \pm 48.3^{b}$ & - & - & - & - & $9.6 \pm 1.3^{b}$ & $10.0 \pm 6.4^{\mathrm{a}}$ \\
\hline June, 2016 & $6.3 \pm 0.6$ & $5.3 \pm 0.3$ & $5.4 \pm 0.7$ & $3.8 \pm 0.2$ & $553.4 \pm 60.7^{c}$ & - & - & - & - & $5.2 \pm 1.3^{\mathrm{a}}$ & $19.5 \pm 1.9^{b}$ \\
\hline
\end{tabular}

Date were analyzed by one-way ANOVA and post-hoc analyzed with duncan test.

Data with different letters means significant among different month $(n=5-30, p<0.05)$.

${ }^{*} p<0.001$.

NPS, number of pistils per spadix; NAS, number of anthers per spadix; WPS, Wet weight of pistils per spadix, WAS, Wet weight of anthers per spadix; NFS, number of fruits per spadix; ANOVA, Analysis of variance.

$\left(16^{\circ} \mathrm{C}\right)$, in the study area had a longer period of occurrence.

In our study, the weight of spathe showed clear seasonal variations and a tendency to increase; these variations may be affected by the fluctuation of fruit weight. The number of fruits decreased by $54 \%$ in June compared to May, and this reduction may be related to the release in seeds by maturation.

In conclusion, there were clear seasonal variations of the morphological features of vegetative shoots and reproductive shoots, density and biomass of $Z$. caespitosa, and it had an optimal growth rate of $9^{\circ} \mathrm{C}-21^{\circ} \mathrm{C}$ from spring to early summer. Reproductive shoots may occur at $10^{\circ} \mathrm{C}$ and seeds may mature and release above $20^{\circ} \mathrm{C}$.

\section{Competing interests}

No potential conflict of interest relevant to this article was reported.

\section{Funding sources}

Not applicable.

\section{Acknowledgements}

Not applicable.

\section{Availability of data and materials}

Upon reasonable request, the datasets of this study can be available from the corresponding author.

\section{Ethics approval and consent to participate}

This article does not require IRB/IACUC approval because there are no human and animal participants.

\section{ORCID}

Nam-Gil Kim

\section{References}

Alexandre A, Cabaço S, Santos R, Serrão EA. Timing and success of reproductive stages in the seagrass Zostera noltii. Aquat Bot. 2006;85:219-23.

Alexandre A, Santos R, Serrão E. Effects of clam harvesting on sexual reproduction of the seagrass Zostera noltii. Mar Ecol Prog Ser. 2005;298:115-22.

Biebl R, McRoy CP. Plasmatic resistance and rate of respiration and photosynthesis of Zostera marina at different salinities and temperatures. Mar Biol. 1971;8:48-56.

Buia MC, Mazzella L. Reproductive phenology of the mediterranean seagrasses Posidonia oceanica (L.) Delile, Cymodocea nodosa (Ucria) Aschers., and Zostera noltii Hornem. Aquat Bot. 1991;40:343-62.

Bulthuis DA. Effects of temperature on photosynthesis and growth of seagrass. Aquat Bot 1987;27:27-40.

Bradley MP, Stolt MH. Landscape-level seagrass-sediment relations in a coastal lagoon. Aquat Bot. 2006;84:121-8.

Costanza R, d’Arge R, de Groot R, Farber S, Grasso M, Hannon $\mathrm{B}$, et al. The value of the world's ecosystem services and natural capital. Nature. 1997;387:253-60.

Den Hartog C. The sea-grasses of the world. Amsterdam, Nederland: North-Holland; 1970.

Dunton KH. Seasonal growth and biomass of the subtropical seagrass Halodule wrightii in relation to continuous measurements of underwater irradiance. Mar Biol. 1994;120:479-89.

Eriksson O. Seedling dynamics and life histories in clonal plants. Oikos. 1989;55:231-38.

Eriksson O, Fröborg H. "Windows of opportunity" for recruitment in long-lived clonal plants: experimental studies of seedling establishment in Vaccinium shrubs. Can J Bot. 1996;74:1369-74 
Green EP, Short FT. World atlas of seagrasses. Berkeley, CA: University of California Press; 2003.

Hemminga MA, Duarte CM. Seagrass ecology. Cambridge, UK: Cambridge University Press; 2000.

Höffle H, Thomsen MS, Holmer M. High mortality of Zostera marina under high temperature regimes but minor effects of the invasive macroalgae Gracilaria vermiculophylla. Estuar Coast Shelf Sci. 2011;92:35-46.

Kendrick GA, Orth RJ, Statton J, Hovey R, Montoya LR, Lowe RJ, et al. Demographic and genetic connectivity: the role and consequences of reproduction, dispersal and recruitment in seagrasses. Biol Rev. 2017 ;92:921-38.

Kendrick GA, Waycott M, Carruthers TJB, Cambridge ML, Hovey R, Krauss SL, et al. The central role of dispersal in the maintenance and persistence of seagrass populations. BioScience 2012;62:56-65.

Kim JB, Park JI, Jung CS, Lee PY, Lee KS. Distributional range extension of the seagrass Halophila nipponica into coastal waters off the Korean peninsula. Aquat Bot. 2009;90:26972.

Kuo J, den Hartog C. Seagrass taxonomy and identification key. In: Short FT, Coles RG, editors. Global seagrass research methods. Amsterdam, Nederland: Elsevier; 2001. p. 31-58.

Lee KS, Dunton KH. Effect of in situ light reduction on the maintenance, growth and partitioning of carbon resources in Thalassia testudinum Banks ex König. J Exp Mar Biol Ecol. 1997;210:53-73.

Lee KS, Kim SH, Kim YK. Current status of seagrass habitat in Korea. In: Finlayson CM, Milton GR, Prentice RC, Davidson NC, editors. The wetland book II: distribution, description, and conservation. Dordrecht, Netherlands: Springer; 2018. p. 1589-96.

Lee KS, Lee SY. The seagrasses of the Republic of Korea. In: Green EP, Short FT, editors. World atlas of seagrasses. Berkeley, CA: University of California Press; 2003. p. 193-8.

Lee KS, Park SR, Kim JB. Production dynamics of the eelgrass, Zostera marina in two bay systems on the south coast of the Korean peninsula. Mar Biol. 2005a;147:1091-108.

Lee KS, Park SR, Kim YK. Effects of irradiance, temperature, and nutrients on growth dynamics of seagrasses: a review. J Exp Mar Biol Ecol. 2007;350:144-75.

Lee SM, Lee SY, Choi CI. Reproductive phenology of four Korean seagrasses, Zostera caespitosa, Z. caulescens, Z. japonica and Z. marina. Ocean Polar Res. 2005b;27:125-33.

Lee SY, Choi CI, Suh Y, Mukai H. Seasonal variation in mor- phology, growth and reproduction of Zostera caespitosa on the southern coast of Korea. Aquat Bot. 2005c;83:250-62.

Lee SY, Lee SM, Choi CI. Phenology and morphometrics change of Zostera caespitosa Miki populations at the Duksan port in the eastern coast of Korea. Korean J Environ Biol. 2002;20:339-46.

Livingston RJ, McGlynn SE, Niu X. Factors controlling seagrass growth in a gulf coastal system: water and sediment quality and light. Aquat Bot. 1998;60:135-59.

Marsh JA, Dennison WC, Alberte RS. Effects of temperature on photosynthesis and respiration in eelgrass (Zostera marina L.). J Exp Mar Biol Ecol. 1986;101:257-67.

McMillan C. Experimental studies on flowering and reproduction in seagrasses. Aquat Bot. 1976;2:87-92.

Morita T, Kakinuma M, Mizuno G, Okumura I, Kokubu H, Kurashima A, Maegawa M. Morphological characteristics of annual Zostera marina shoots at various germination temperatures. Aquat Bot. 2010;92:49-54.

Omori Y. Zosteraceous species endemic to Japan. Bull Water Plant Soc. 1993;51:19-25.

Orth RJ, Carruthers TJB, Dennison WC, Durate CM, Fourqurean JW, Heck KL, et al. A global crisis for seagrass ecosystems. BioScience. 2006;56:987-96.

Orth RJ, Harwell MC, Bailey EM, Bartholomew A, Jawad JT, Lombana AV, et al. A review of issues in seagrass seed dormancy and germination: implications for conservation and restoration. Mar Ecol Prog Ser. 2000;200:277-88.

Phillips RC, McMillan C, Bridges KW. Phenology of eelgrass, Zostera marina L., along latitudinal gradients in North America. Aquat Bot. 1983;15:145-56.

Phillips RC, Mennez EG. Seagrass. Washington, DC: Smithsonian Institution Press; 1988. p. 1-106.

Plus M, Deslous-Paoli J, Dagault F. Seagrass (Zostera marina L.) bed recolonization after anoxia-induced full mortality. Aquat Bot. 2003;77:121-34.

Shin H, Choi HK. Taxonomy and distribution of Zostera (Zosteraceae) in eastern Asia, with special reference to Korea. Aquat Bot. 1998;60:49-66.

Shin HC, Cho KH, Oh YS. Zostera geojeensis, a new species of seagrass from Korea. Algae. 2002;17:71-4.

Short F, Carruthers T, Dennison W, Waycott M. Global seagrass distribution and diversity: a bioregional model. J Exp Mar Biol Ecol. 2007;350:3-20.

Short FT, Wyllie-Echeverria S. Natural and human-induced disturbance of seagrasses. Environ Conserv. 1996;23:17-27. 
Waycott M, Duarte CM, Carruthers TJB, Orth RJ, Dennison WC, Olyarnike S, et al. Accelerating loss of seagrass across the globe threatens coastal ecosystems. Proc Natl Acad Sci. 2009;106:12377-81.

Yoon JS, Kim NG. Phenology of Zostera marina at Tongyeong in southern coast of Korea. J Mar Biosci Biotechnol. 2019;11:62-70.

Zhang PD, Liu YS, Guo D, Li WT, Zhang Q. Seasonal variation in growth, morphology, and reproduction of eelgrass Zostera marina on the eastern coast of the Shandong peninsula, China. J Coast Res. 2016;32:315-22. 